\title{
Two new species of lithobiid centipedes (Chilopoda: Lithobiomorpha: Lithobiidae) from southern Kazakhstan
}

\author{
Ава новых вида многоножкек-костянок (Chilopoda: \\ Lithobiomorpha: Lithobiidae) из Юэкного Казахстана
}

\author{
Yu.V. Dyachkov ${ }^{1}$, G.Sh. Farzalieva ${ }^{2}$ \\ Ю.В. Аььячков ${ }^{1}$, Г.Ш. Фарзалиева ${ }^{2}$
}

${ }^{1}$ Altai State University, Lenin Avenue, 61, Barnaul 656049 Russia. E-mail: dyachkov793@mail.ru
${ }^{2}$ Perm State University, Bukireva Street, 15, Perm 614600 Russia. E-mail: g.farzalieva@yandex.ru
${ }^{1}$ Алтайский государственный университет, проспект Ленина, 61, Барнаул 656049 Россия.
${ }^{2}$ Пермский государственный национальный исследовательский университет, ул. Букирева, 15, Пермь 614990 Россия.

KEY WORDS: Taxonomy, Lithobiidae, two new species, Tian-Shan, southern Kazakhstan.

КЛЮЧЕВЫЕ СЛОВА: Таксономия, Lithobiidae, два новых вида, Тянь-Шань, Южный Казахстан.

ABSTRACT. Two new species of lithobiid centipedes are described: Lithobius (Monotarsobius) trisspurus sp.n and L. (M.) monocoxaporus sp.n., both from the Jambyl Region of Kazakhstan, and both belonging to the ferganensis group.

How to cite this article: Dyachkov Yu.V., Farzalieva G.Sh. 2018. Two new species of lithobiid centipedes (Chilopoda: Lithobiomorpha: Lithobiidae) from southern Kazakhstan // Arthropoda Selecta. Vol.27. No.3. P.210-218. doi: 10.15298/arthsel. 27.3.03

РЕЗЮМЕ. Описаны два новых вида: Lithobius (Monotarsobius) trisspurus sp.n and L. (M.) monocoxaporus sp.n. из Жамбылской области Казахстана. Оба вида принадлежат к группе ferganensis.

\section{Introduction}

Knowledge of the lithobiid centipede fauna of Kazakhstan is extensive, but this huge territory is prospected very fragmentarily [Sseliwanoff, 1881; Attems, 1904; Lignau, 1929; Zalesskaja, 1978; Eason, 1997; Farzalieva et al., 2003, 2004, 2017; Farzalieva, 2006, 2017; Tuf, 2007; Tuf et al., 2010; Tishkov, 2009; Bragina, 2012, 2016; Dányi, Tuf, 2012; Dyachkov et al., 2016; Dyachkov, 2017]. Altogether, the lithobiid fauna of Kazakhstan presently comprises 32 species, 27 of them being known from eastern Kazakhstan (the East Kazakhstan and Almaty regions). Southern Kazakhstan (the South Kazakhstan, Kyzylorda and Jambyl regions) remains one of the poorly-studied parts, with only 3 species recorded from that area: Hessebius perelae Zalesskaja, 1978, Cermatobius kirgisicus (Zalesskaja, 1972) and Australobius magnus (Trozina, 1894) [Zalesskaja, 1978; Dyachkov, 2017].

Prompted by new material from southern Kazakhstan (Jambyl Region), we put on record another two species, both new Lithobius Leach, 1814 from the subgenus Monotarsobius Verhoeff, 1905, and both belonging to the ferganensis group.

\section{Material and Methods}

The studied material was collected in the Jambyl Region (Map) by the first author in 2017. Centipedes were taken by hands and preserved in $70 \%$ ethanol.

The pictures have been taken using an Olympus OMD EM-10 digital camera with a Panasonic Lumix H-H025 $25 \mathrm{~mm} \mathrm{f/1.7} \mathrm{lens} \mathrm{mounted} \mathrm{on} \mathrm{a} \mathrm{Zeiss} \mathrm{micro-}$ scope and with an Axio Cam ERc-5s (Zeiss) digital camera attached to a Stemi 2000-C stereo microscope. The images were prepared using Helicon Focus 6.7.1 software. The line drawings were edited with Adobe Photoshop CS 6.1 and Paint.net 4.0. The mouthparts, legs and body segments of the new species were cleared in $10 \% \mathrm{KOH}$ and mounted in permanent preparations in sandarac medium [Krasheninnikov, 2011] for examination.

The type material is deposited in the collection of the Zoological Museum of the Moscow State University, Russia (ZMMU), with a few paratypes housed in the collections of

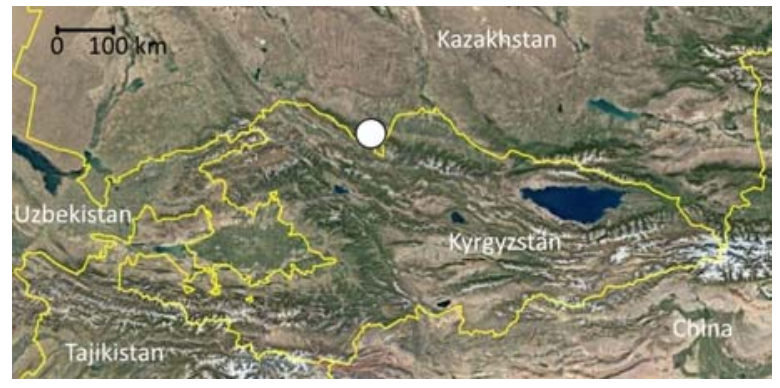

Map. Position of the collecting locality (circle).

Карта. Расположение места сбора материала (круг). 


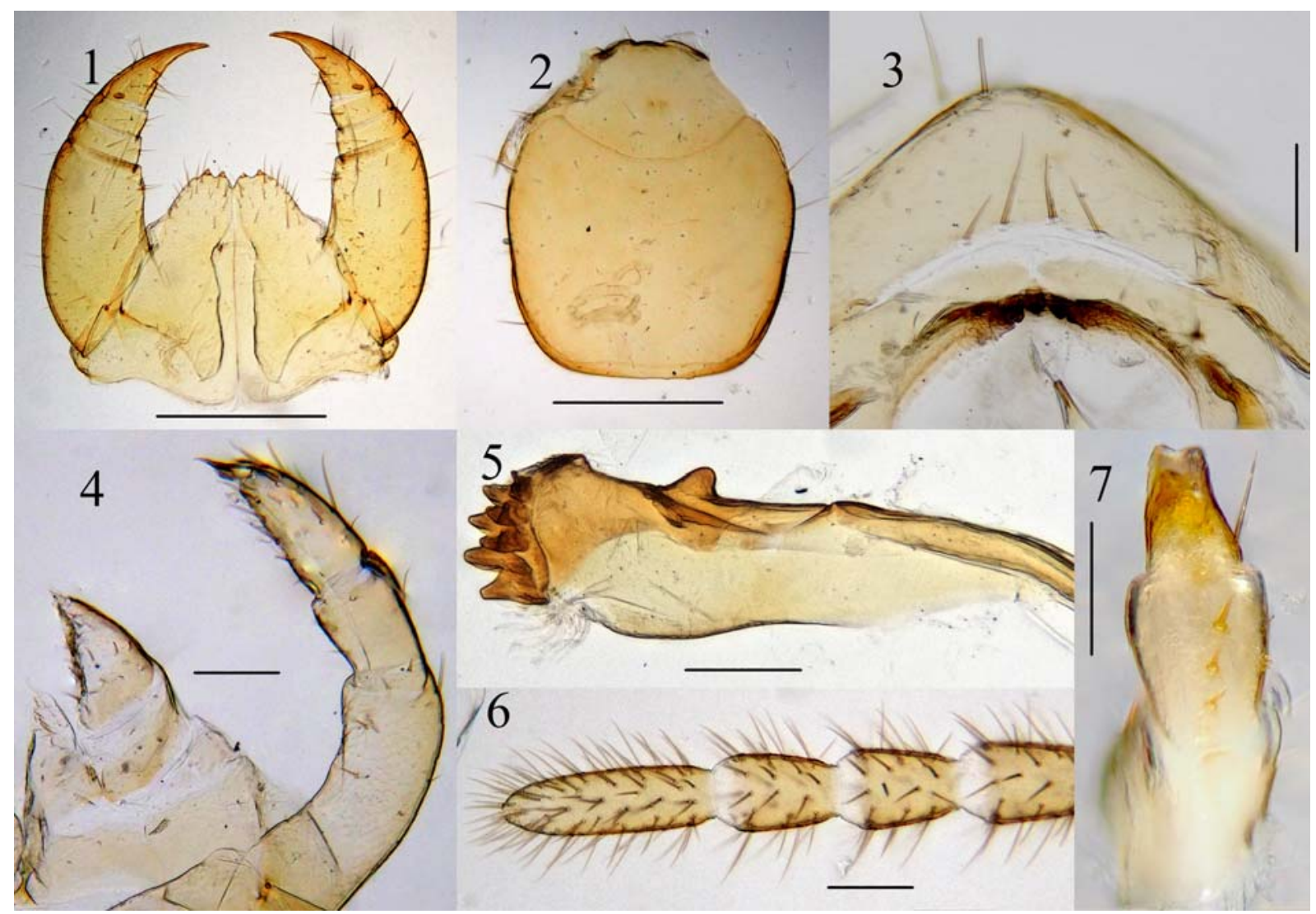

Figs 1-7. Lithobius trisspurus sp.n., female paratypes: 1 - forcipula, ventral view; 2 - cephalic plate, dorsal view; 3 - clypeus and labrum, ventral view; 4 - left part of maxillary complex, ventral view; 5 - mandible; 6 - terminal part of antenna, lateral view; 7 female gonopod, dorsal view. Scale: $1,2-0.5 \mathrm{~mm}, 3-7-0.1 \mathrm{~mm}$.

Рис. 1-7. Lithobius trisspurus sp.n., паратипы самок: 1 - ногочелюсти, вентрально; 2 - головная капсула, дорсально; 3 клипеус и лабрум, вентрально; 4 - левая часть максиллярного комплекса, вентрально; 5 - мандибула; 6 - конечная часть антенны, латерально; 7 - гонопод самки, дорсально. Масштаб: 1, 2-0,5 мм, 3-7 - 0,1 мм.

the Altai State University, Barnaul (ASU) and the Perm State University, Perm (PSU). The terminology for external anatomy follows that of Bonato et al. [2010]. Body length was measured from the anterior margin of the cephalic plate to the posterior end of the postpedal tergite. The following abbreviations are used in the text and tables: T, TT tergite, tergites, $\mathrm{V}$ - ventral, D - dorsal, $\mathrm{C}-$ coxa, $\mathrm{Tr}$ trochanter, $\mathrm{P}$ - prefemur, $\mathrm{F}$ - femur, Ti - tibia, Ts, Tss tarsus, tarsi.

\section{Taxonomic part}

Both new species belong to the subgenus Monotarsobius (legs 1-13 with unipartite tarsi, antennae with about 20 articles, $2+2$ forcipular coxosternal teeth, TT without triangular projections) and both represent the ferganensis group which comprises L. ferganensis (Trotzina, 1894), L. turkestanicus Attems, 1904, L. sseliwanoffi Garbowski, 1897, L. steppicus Farzalieva et Zalesskaja, 2003, L. evsyukovi Zuev, 2017, L. ketmenensis Farzalieva, 2006, L. amplinus Farzalieva, 2006, L. farzalievae Dányi et Tuf, 2012. This group is widespread in eastern Europe, the Caucasus and Central Asia, being characterized by small or medium sizes (from $6.1 \mathrm{~mm}$ in L. steppicus to $18.5 \mathrm{~mm}$ in L. farzalievae); the structure of the apical claw (bi- or tridentate), the dorsolateral armature of the female gonopods and very similar secondary sexual features on male $15 \mathrm{Ti}$. Lithobius turkestanicus Attems, 1904 was regarded as a junior subjective synonym of L. ferganensis by Eason [1997], but this synonymy was questioned by Farzalieva [2006], based on a study of additional abundant material. The main features of the ferganensis group are summarized in Tab. 1.

\section{Lithobius (Monotarsobius) trisspurus sp.n.} Figs $1-12$.

MATERIAL. Holotype $\sigma^{7}$ (ZMMU Rc 7888), southern Kazakhstan, Jambyl Region, Kyrgyz Ala-Too Mt Range, Dzyndybay River valley, stony mountain steppe with Juniperus, under stones, $42^{\circ} 35^{\prime} 33^{\prime \prime} \mathrm{N}, 73^{\circ} 18^{\prime} 21^{\prime \prime} \mathrm{E}, 2370 \mathrm{~m}$ a.s.1., 12-14.VIII.2017.

Paratypes: 2 우 (ZMMU Rc 7889); 2 우 (ASU No 33); $1 \sigma^{\text {乃 }, ~} 1$ $q$ (PSU No 613), same data as holotype.

ETYMOLOGY. To emphasize the number of female gonopodal spurs.

DIAGNOSIS. A medium-sized (9-13 mm) Lithobius with 8-10 ocelli in 2 rows, Tömösváry's organ as large as the nearest ocelli; 20-22 antennal articles; forcipular coxos- 


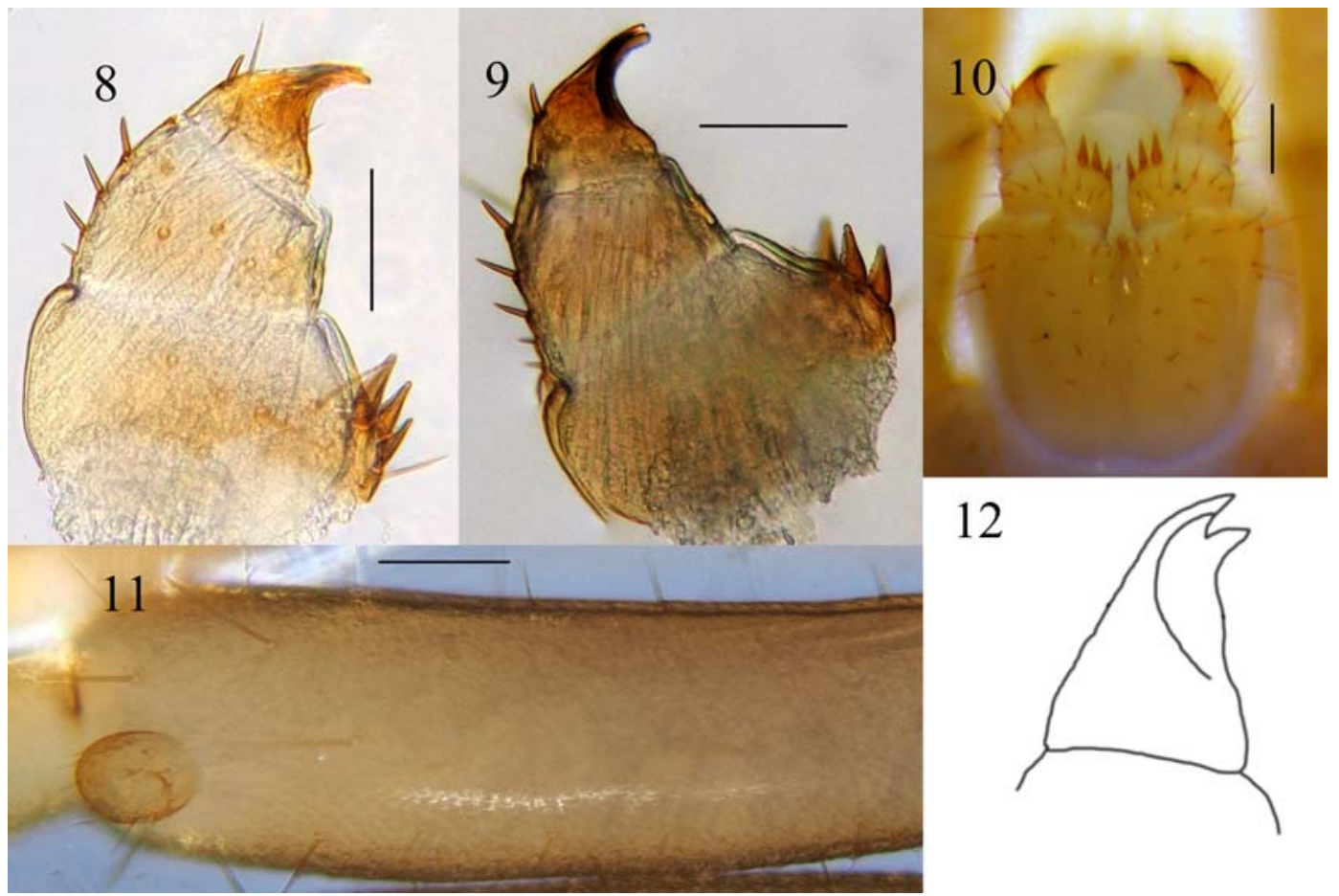

Figs 8-12. Lithobius trisspurus sp.n., paratypes: 8,9- female gonopod, lateral view; 10 - female gonopods, ventral view; $11-$ tibia of 15 leg of male with wart, dorsal view; 12 - claw of female gonopod, lateral view. Scale $0.1 \mathrm{~mm}$.

Рис. 8-12. Lithobius trisspurus sp.n., паратипы: 8, 9 - гонопод самки, латерально; 10 - гоноподы самки, вентрально; 11 голень 15 ноги самца с бородавкой, дорсально; 12 - коготь гонопода самки, латерально. Масштаб 0,1 мм.

ternite with $2+2$ teeth and setiform porodonts; TT with rounded posterior corners; legs $1-13$ with unipartite tarsi; legs 15 without accessory spine; DCa present on 12(13)-15 legs; coxal pores $1-2$ on legs $12-15$; male Ti15 with a distodorsal wart with a crater armed by $10-12$ thin setae; female with $3+3$ gonopodal spurs and a bidentate claw, $1^{\text {st }}$ segment of gonopods without dorsal spines, $2^{\text {nd }}$ segment with 3-5 dorsal spines, $3^{\text {rd }}$ segment with one dorsal spine.

DESCRIPTION. Holotype. Body $11 \mathrm{~mm}$ long, brown, cephalic plate, forcipules, antennae, legs 14-15 and TT 1415 a bit darker. Head as in Fig. 2; median diastema Vshaped. Head a little broader than T1, ratio 1.2:1.

Antennae with 20 articles covered with dense, light, erect sensilla. Length to breadth ratio of terminal article 3.5:1 (Fig. 6). Antennae extending back to the middle of T6.

Ocelli: 8 on each side in two rows. Tömösváry's organ as large as nearest ocelli, rounded.

Coxosternum with $2+2$ acute teeth and thin setiform porodonts. Shoulders very strongly sloping behind porodonts (Fig. 1).

All TT with rounded posterior corners, macrotergites poorly emarginated. T1 breadth $0.61 \mathrm{~mm}$, T8 breadth 0.85 $\mathrm{mm}$. Terminal $\mathrm{T}$ slightly emarginate at caudal margin, length to breadth ratio $1: 0.7$.

Legs 1-13 with clearly unipartite Tss. Legs $1-14$ with one true accessory spine (in addition, legs 1-13 with a seta located near spine, similar in shape to accessory spine). Legs 15 without accessory spines. Legs 14 and 15 slightly incrassate. $15 \mathrm{Ti}$ with a distodorsal wart with a crater at apex, armed 10-12 very thin and light setae (Fig. 11). Leg plectrotaxy as in Tab. 2.

DCa developed from legs 12 on. Coxal pores small, rounded, separated from one another by a distance about 4 times greater than their own diameter, formula 2211. Gonopods 1-segmented, with one or two setae placed at gonopodal middle.

Male variation. Body $13 \mathrm{~mm}$ long. Antennae with 22 antennomeres, length to breadth ratio of terminal antennomere 3:1. Ocelli: $9+10$ in 2 rows. Each gonopod with one seta. Coxal pore formula 2221. DCa developed on legs 1315.

Female. Body 10.5 (9-12) mm long. Head broader than $\mathrm{T} 1$, ratio $1.2: 1-1.5: 1.2$

Labrum, maxillae and mandibles as in Figs 3-5.

Ocelli: $8-9$ on each side. Antennae with 22 articles. T1 breadth $0.6 \mathrm{~mm}$, T8 breadth $0.9 \mathrm{~mm}$. Leg plectrotaxy as in Tab. 3. Coxal pore formula 2221. Terminal $\mathrm{T}$ length to breadth ratio 1:0.9.

Gonopods: with $3+3$ acute spurs and a bidentate claw (teeth well-developed) (Figs 10,12); $1^{\text {st }}$ segment without spines, $2^{\text {nd }}$ segment with $3-5$ dorsal spines and $3^{\text {rd }}$ segment with one dorsal spine (Figs 7-9).

REMARKS. Females of this new species differ from those of the other species of the ferganensis group by $3+3$ gonopodal spurs, vs. $2+2$ in the females of the other members of the ferganensis group (Tab. 1).

DISTRIBUTION. Only the terra typica.

\section{Lithobius (Monotarsobius) monocoxaporus sp.n.} Figs 13-27.

MATERIAL. Holotype $\sigma^{7}$ (ZMMU Rc 7890), southern Kazakhstan, Zhambyl Region, Kyrgyz Ala-Too Mt. Range, Dzhyndybay River valley, stony mountain steppe with Juniperus, under stones, $42^{\circ} 35^{\prime} 33^{\prime \prime} \mathrm{N}, 73^{\circ} 18^{\prime} 21^{\prime \prime} \mathrm{E}, 2370 \mathrm{~m}$ a.s.1., 12-14.VIII.2017. 


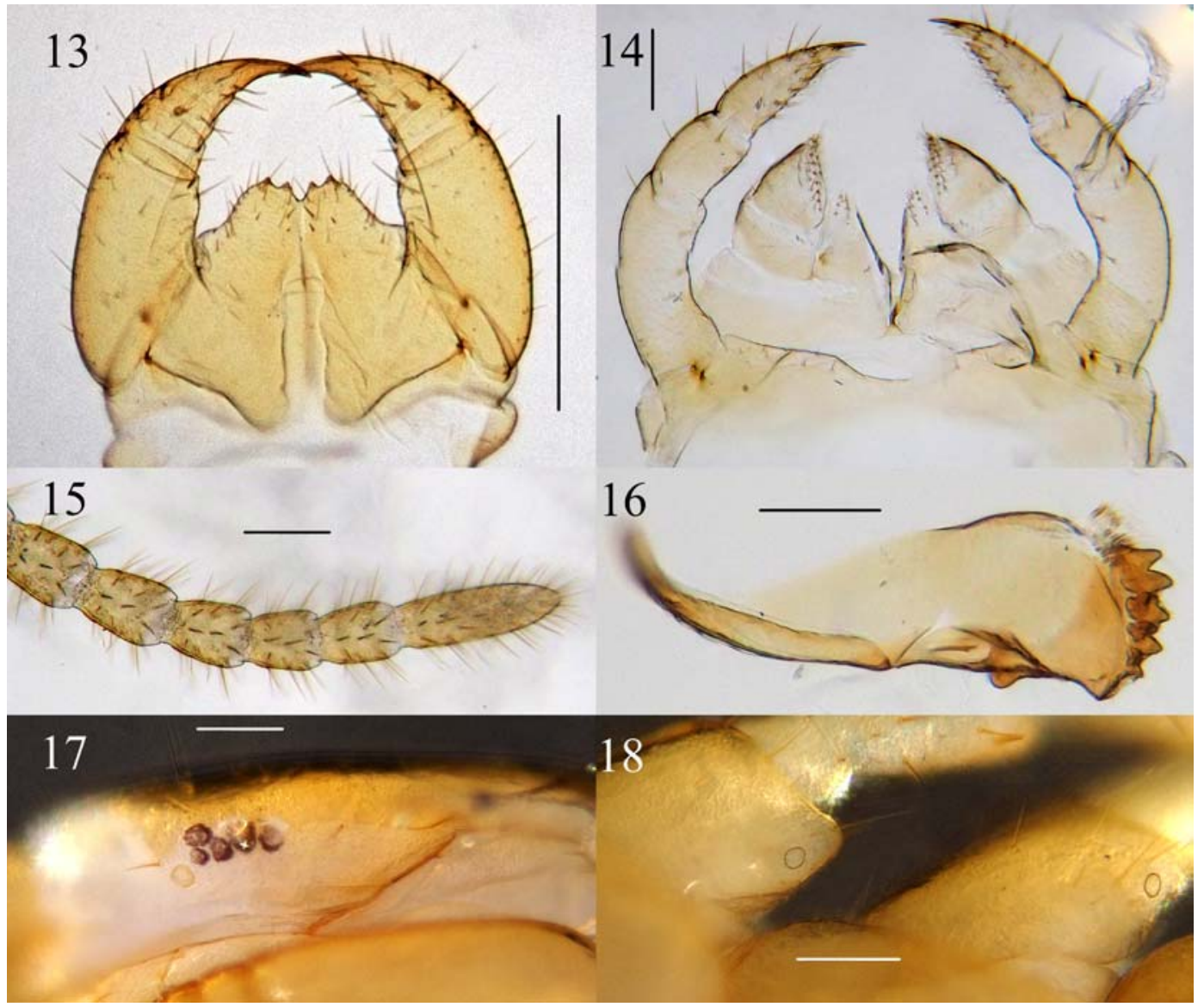

Figs 13-18. Lithobius monocoxaporus sp.n., paratypes: 13 - forcipula, ventral view (female); 14 - maxillary complex, ventral view (female); 15 - terminal part of antenna, lateral view (female); 16 - mandible (female); 17 - ocelli, lateral view (male); 18 - 13 and 14 coxae, ventral view (female). Scale: $13-0.5 \mathrm{~mm}, 14-18-0.1 \mathrm{~mm}$.

Рис. 13-18. Lithobius monocoxaporus sp.n., паратипы: 13 - ногочелюсти, вентрально (самка); 14 - максиллярный комплекс, вентрально (самка); 15 - конечная часть антенны, латерально (самка); 16 - мандибула (самка); 17 - глазки, латерально (самец); $18-13$ и 14 тазики, вентрально (самка). Масштаб: $13-0,5$ мм, 14-18-0,1 мм.

Paratypes: $7 \sigma^{7} \sigma^{7}, 7$ 우, 6 juv. (ZMMU Rc 7891), $4 \sigma^{7} \sigma^{7}, 3$ 우, 1 juv. (ASU No 34); $2 O^{\pi} O^{\mathrm{T}}, 2$ 우 (PSU No 614), same data as holotype.

NAME. To emphasize the number of coxal pores.

DIAGNOSIS. A small-sized Lithobius (up to $10 \mathrm{~mm}$ long), 4-8 ocelli in 1-2 rows, Tömösváry's organ of the same size as the nearest ocelli; antennae composed of 18-20 articles (usually 20); forcipular coxosternite with $2+2$ teeth and setiform porodonts; pairs of legs 14 and 15 slightly swollen in both sexes, legs 15 without accessory spines; DCa developed from legs 12 on; number of coxal pores varying from 1 to 2 ; distodorsal part of male $15 \mathrm{Ti}$ with an oval wart with a crater; male gonopods each with a single seta; female gonopods each with $2+2$ conical spurs and a tridentate claw, $1^{\text {st }}$ segment without dorsal spines, $2^{\text {nd }}$ segment with two dorsolateral spines, $3^{\text {rd }}$ segment with 1 dorsal spine.

DESCRIPTION. Holotype. Body $9 \mathrm{~mm}$ long, yellow, head a bit darker. All TT with rounded posterior corners, macrotergites poorly-emarginated, terminal $\mathrm{T}$ elongate, emarginated at caudal margin, length to breath ratio 1.3:1.
Head length $0.5 \mathrm{~mm}$, breadth $0.55 \mathrm{~mm}$; head a little broader than $\mathrm{T} 1$ (breadth $0.49 \mathrm{~mm}$ ).

Antennae about 2 times as long as head, with $20+20$ antennomeres, covered with dense, light, erect sensilla. Length to breadth ratio of terminal antennomere $4: 1$, larger than previous two (Fig. 15).

Ocelli: 6 on each side, arranged in a single row. Tömösváry's organ of the same size as the nearest ocelli, rounded.

Coxosternite with $2+2$ acute teeth and well-expressed porodonts, shoulders very strongly sloping behind porodonts (Fig. 13).

Legs 1-13 with clearly unipartite Tss; DCa developed from legs 12 on. Legs 1-14 each with one true accessory posterior spine; legs 15 without accessory spines. Leg plectrotaxy as in Tab. 4. Tr, P, F and Ti of legs 14 and 15 slightly incrassate (Figs 20-21), 15Ti with a distodorsal oval wart with a crater surrounded by several very thin short setae (Figs 19, 27).

Рис. 25-30. Lithobius monocoxaporus sp.n. (паратипы) (25-27) и L. farzalievae Dányi et Tuf, 2012 (паратипы) (28-30): 25 зубной край коксостернита ногочелюсти, вентрально; 26 - гонопод самки, латерально; 27 - голень 15 ноги, латерально (самец); 28 - зубной край коксостернита ногочелюсти, вентрально; 29 - гонопод самки, латерально; 30 - голень 15 ноги, латерально (самец). Масштаб 0,1 мм. 

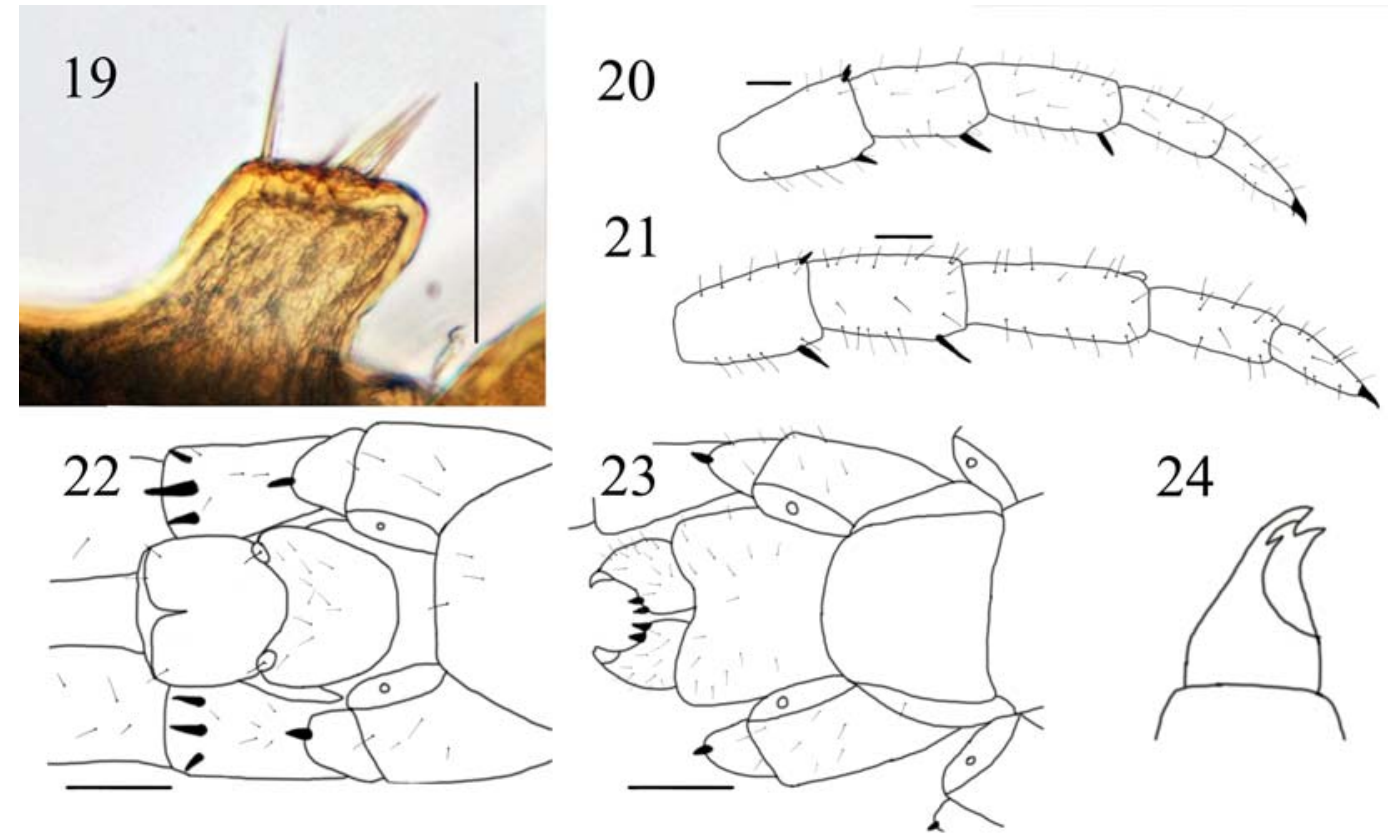

Figs 19-24. Lithobius monocoxaporus sp.n., paratypes: 19 - wart on 15 tibia (male); 20 - leg 14, lateral view (male); 21 - leg 15, lateral view (male); 22 - terminal part of body, ventral view (male); 23 - same of female; 24 - claw of female gonopod. Scale: 19 $0.05 \mathrm{~mm}, 20-23-0.1 \mathrm{~mm}$

Рис. 19-24. Lithobius monocoxaporus sp.n., паратипы: 19 - бородавка на голени 15 ноги (самец); 20 - нога 14, латерально (самец); 21 - нога 15, латерально (самец); 22 — задняя часть тела, вентрально (самец); 23 — то же, самка; 24 — коготь гонопода самки. Масштаб: $19-0,05$ мм, 20-23-0,1 мм.

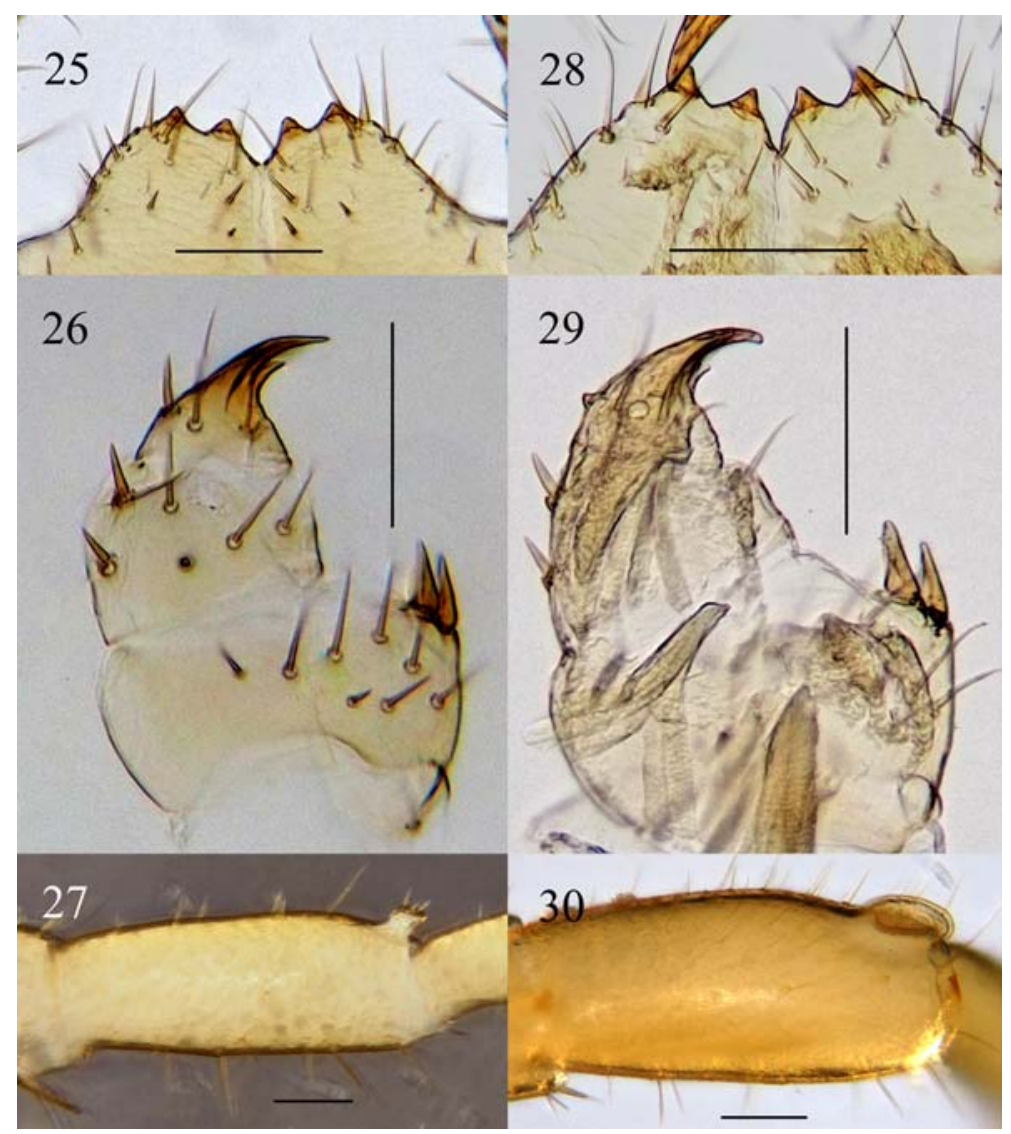

Figs 25-30. Lithobius monocoxaporus sp.n. (paratypes) (25-27) and L. farzalievae Dányi et Tuf, 2012 (paratypes) (28-30): 25 - dental margin of forcipular coxosternite, ventral view; 26 - female gonopod, lateral view; 27 - tibia of 15 leg, lateral view (male); 28 - dental margin of forcipular coxosternite, ventral view; 29 - female gonopod, lateral view; 30 - tibia of 15 leg, lateral view (male). Scale $0.1 \mathrm{~mm}$. 
A single coxal pore on each of legs $12-15$, large and rounded (Fig. 22). Gonopods 1-segmented, each with a single seta.

Male variation. Body length 7-9 $\mathrm{mm}$. Length to breadth ratio of terminal $\mathrm{T}$ 1:0.8. Antennae with 18-20 articles. Number of ocelli varying from 4 to 8 (Fig. 17). DCa developed on legs 13-15. Leg plectrotaxy as in Tab 5. Coxal pore formula 1111.

Female variation. Body length 7-10 mm. Coxosternal teeth as in Fig. 25. Maxillae and mandibles as in Figs 14 and 16. Macrotergites poorly-emarginated. Coxal pores as in Figs 18 and 23, formula 111(2)1. Antennae with 19-20 articles. Number of ocelli varying from 5 to 7 . Gonopods: with $2+2$ conical spurs (one specimen with $2+3$ spurs) separated from one another by less than their diameter at base (Fig. 23); $1^{\text {st }}$ segment without spines, $2^{\text {nd }}$ segment with two dorsolateral spines, $3^{\text {rd }}$ segment with a single dorsal spine (Fig. 26); claw tridentate (all teeth well-developed) (Fig. 24)

REMARKS. Based on some of the main characters (Tab. 1), L. monocoxaporus sp.n. is extremely similar to L. farzalievae Dányi et Tuf, 2012 (see Figs 26, 29), but differs by the shape of the coxosternite (cf. Fig. 25 and Fig. 28) Moreover, males of this species differ from those of the other congeners by the shape of their wart on $15 \mathrm{Ti}$ (i.e. the wart is wider in L. farzalievae than in L. monocoxaporus sp.n.; cf. Fig. 27 and Fig. 30).

Based on the structure of the female gonopods and other main characters (see details [Pei et al., 2011; Ma et al., 2012, 2014]), L. monocoxaporus sp.n. also resembles three Chinese Monotarsobius, viz. L. (M.) monoforaminis Ma, Pei, Wu, Lin, Gai, 2012, L. (M.) zhangi Ma, Pei, Hou, Zhu, 2014 and L. (M.) songi Pei, Ma, Shi, Wu, Zhou, 2011, but differs by the presence of a wart on male $15 \mathrm{Ti}$.

In addition, the new species is similar to L. ferganensis (Trotzina, 1894) and L. steppicus Farzalieva et Zalesskaja, 2003 (Tab. 1), especially in the shape of the wart on male $15 \mathrm{Ti}$ and in some details of female gonopodal structure (i.e. $2+2$ spurs and two spines on $2^{\text {nd }}$ segment), but it differs by the tridentate claw of the female gonopods (vs. bidentate in L. ferganensis and L. steppicus).

DISTRIBUTION. Only the terra typica.

ACKNOWLEDGMENTS. The first author wishes to thank R.V. Yakovlev (Barnaul, Russia) and I.I. Temreshev (Almaty, Kazakhstan) for their help in the organization of a field trip. Special thanks go to colleague A.A. Fomichev (Barnaul, Russia). Thanks go also to P.V. Golyakov, director of the Tigirek Nature Reserve, and its staff members, E.A. Davydov and D.V. Kuzmenkin (all from Barnaul, Russia) for their logistic help. Sergei Golovatch kindly edited the English of an advanced draft.

\section{References}

Attems C. 1904. Central- und hoch-asiatische Myriopoden // Zoologische Jahrbücher, Abteilung für Systematik. Bd.20. S.113130 .

Bonato L., Edgecombe G.D., Lewis J.G., Minelli A., Pereira L.A., Shelley R.M., Zapparoli M. 2010. A common terminology for the external anatomy of centipedes (Chilopoda) // ZooKeys. Vol.69. P.17-51.

Bragina T.M. 2012. [An inventory of the invertebrate fauna of the Naurzum Nature Reserve] // Material of the II Internationa Scientific Conference "Biodiversity of Asian steppes", Kostanay. P.140-145 [in Russian].

Bragina T.M. 2016. Soil macrofauna (invertebrates) of Kazakhstanian Stipa lessingiana dry steppe // Hacquetia. Vol.15. No.2. P.105-112.
Dányi L., Tuf I.H. 2012. Lithobius (Monotarsobius) franciscorum sp. nov., a new lithobiid species from the Altai, with a key to the Central Asian species of subgenus (Chilopoda: Lithobiomorpha) // Zootaxa. Vol.3182. P.16-28.

Dyachkov Yu.V., Farzalieva G.Sh., Fomichev A.A. 2016. New data on the Centipede (Chilopoda) fauna of East Kazakhstan region // Biological Bulletin of Bogdan Chmelnitskiy Melitopol State University. Vol.6. No.3. P.438-442.

Dyachkov Yu.V. 2017. [New data on the Australobius magnus (Trotzina, 1894) (Chilopoda: Lithobiomorpha: Lithobiidae) from Southern Kazakhstan] // Ukrainian Journal of Ecology. Vol.7. No.4. P.440-443 [in Russian].

Eason E.H. 1997. On some Lithobiomorpha from the mountains of Kirgizia and Kazakhstan (Chilopoda) // Arthropoda Selecta. Vol.6. No.1/2. P.117-121.

Farzalieva G.Sh. 2006. New species of the lithobiid genus Lithobius (Monotarsobius) (Chilopoda: Lithobiomorpha: Lithobiidae) from eastern Kazakhstan // Arthropoda Selecta. Vol.15. No.2. P.99-117.

Farzalieva G.Sh. 2017. [New species of lithobiomorph centipedes of the genus Hessebius Verhoeff, 1941 (Lithobiomorpha, Lithobiidae) from eastern Kazakhstan] // Zoologicheskii zhurnal. Vol.96. P.30-36 [in Russian, with English summary].

Farzalieva G.Sh., Zalesskaja N.T. 2003. On two remarkable species of lithobiid centipedes (Chilopoda: Lithobiomorpha: Lithobiidae) from the steppe of the southern Urals, Russia // Arthropoda Selecta. Vol.11. No.4. P.265-269.

Farzalieva G.Sh., Zalesskaja N.T., Edgecombe G.D. 2004. A new genus and species of lithobiomorph centipede (Chilopoda: Lithobiomorpha: Anopsobiidae) from eastern Kazakhstan // Arthropoda Selecta. Vol.25. No.1. P.219-224.

Farzalieva G.Sh., Nefediev P.S., Tuf I.H. 2017. Revision of Disphaerobius Attems, 1926 (Chilopoda: Lithobiomorpha: Lithobiidae: Pterygoterginae), a centipede genus with remarkable sexual dimorphism // Zootaxa. Vol.4258. No.2. P.212-137.

Krasheninnikov A.B. 2011. Mounting technique of entomological preparations in sandarac medium // Euroasian Entomological Journal. Vol.10. No.3. P. 278-279.

Lignau N.G. 1929. Zur Kenntnis der zentralasiatischen Myriopoden // Zoologischer Anzeiger. Bd.58. S.159-175.

Ma H., Pei S., Wu D., Lin H., Gai Y. 2012. Lithobius (Monotarsobius) monoforaminis sp. n., a new species of lithobiid centipede from central China (Chilopoda, Lithobiomorpha, Lithobiidae) // ZooKeys. Vol.193. P.79-87.

Ma H., Pei S., Hou X., Zhu T. 2014. Lithobius (Monotarsobius) zhangi sp. n., a new species from Eastern China (Chilopoda, Lithobiomorpha, Lithobiidae) // ZooKeys. Vol.459. P.1-10.

Pei S., Ma H., Shi B., Wu D., Zhou W. 2011. A new species of Lithobius (Monotarsobius) Verhoeff, 1905 (Lithobiomorpha, Lithobiidae) from China // ZooKeys. Vol.82. P.59-66.

Sseliwanoff A.V. 1881. Neue Lithobiiden aus Sibirien und Central-Asien // Zoologischer Anzeiger. Bd.4. H.73. S.15-17.

Tishkov A.A. (ed.). 2009. [Animals of the argillaceous semi desert of the trans-Volga Region (synopsis of faunas and ecological characters)]. Moscow: KMK Scientific Press. 164 p. [in Russian].

Tuf I.H. 2007. [Diversity of selected taxa of invertebrates in the Altai (East Kazakhstan)] // Modern approaches to biodiversity protection in the context of steady development achievement of the Republic of Kazakhstan. Materials of International Kazakh-Czech Scientific Conference, Ust-Kamenogorsk, 2007. P.56-64 [in Czech, with English summary].

Tuf I.H., Dányi L., Kuda F., Chilachula J. 2010. [Centipedes of Kazakhstan - new records from Altai] // High Mountain Soils Biodiversity. 18-20 October 2010. Ilia State University, Institute of Zoology, Tbilisi. P.11-12.

Zalesskaja N.T. 1978. [Identification book of the lithobiomorph centipedes of the USSR]. Moscow: Nauka Publ. 212 p. [In Russian]

Zuev R.V. 2017. Two new species of lithobiid centipedes (Chilopoda: Lithobiomorpha) from the northern Caucasus, Russia // Arthropoda Selecta. Vol.26. No.1. P.15-24.

Responsible editor S.I. Golovatch 


\begin{tabular}{|c|c|c|c|c|c|c|c|c|c|c|}
\hline  & 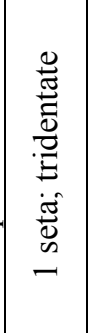 & 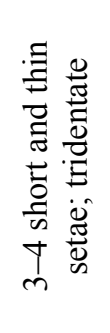 & 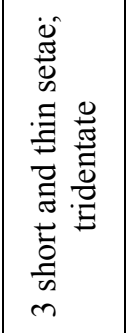 & 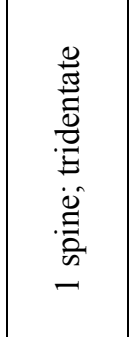 &  &  & 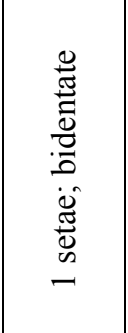 & 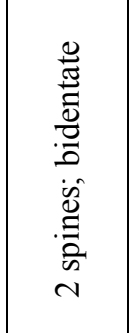 & 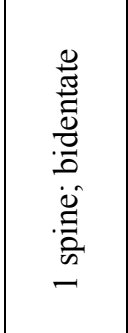 &  \\
\hline  & 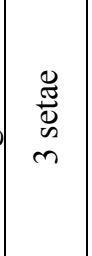 & $\begin{array}{l}\tilde{m} \\
\frac{\pi}{0} \\
\infty \\
m \\
m\end{array}$ & 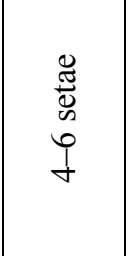 & 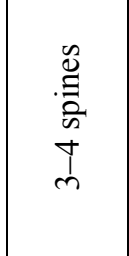 &  & $\begin{array}{l}\mathscr{w} \\
\stackrel{\Xi}{0} \\
\text { के } \\
\text { v }\end{array}$ & 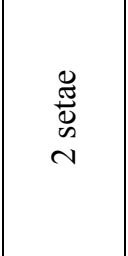 & 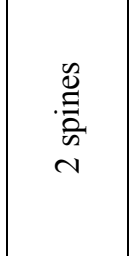 & 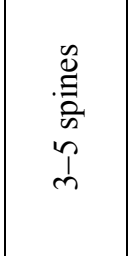 & 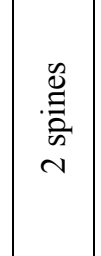 \\
\hline 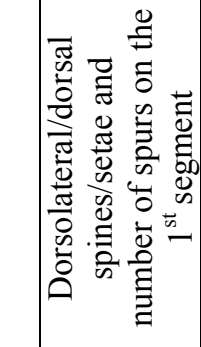 & 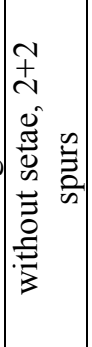 & 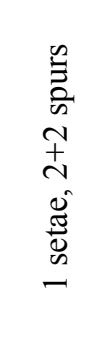 & 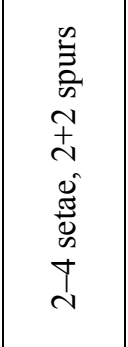 & 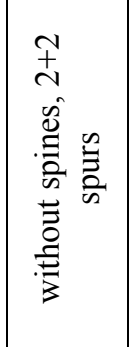 & 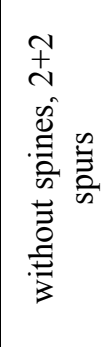 & 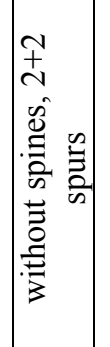 &  & 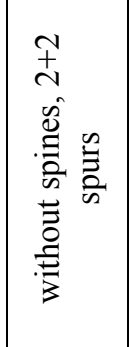 &  & 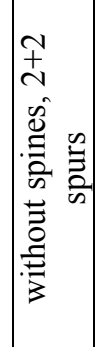 \\
\hline  & 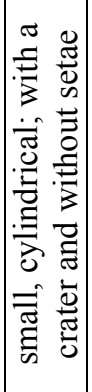 & 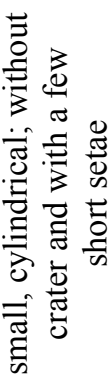 &  &  &  & 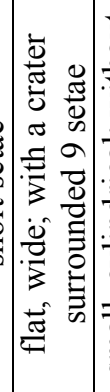 &  & 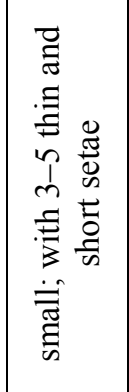 &  & 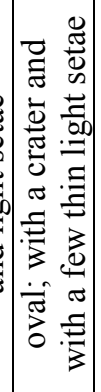 \\
\hline 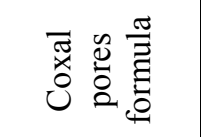 &  & 等苫 & 旁蕜 & ल্ণী & 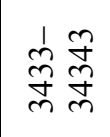 & $I$ & \begin{tabular}{l}
\multirow{N}{\mathbb{Z}}{} \\
$\mathbb{Z}$
\end{tabular} &  & $\overrightarrow{\bar{\lambda}} \overline{\mathcal{N}}$ & $\underset{\Xi}{\vec{\Xi}}$ \\
\hline 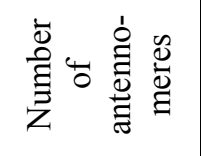 & $\stackrel{\sim}{~}$ & i & $\begin{array}{l}\overrightarrow{\bar{\alpha}} \\
\infty\end{array}$ & $\begin{array}{l}\vec{\jmath} \\
\Omega\end{array}$ & $\begin{array}{l}\text { ते } \\
\text { ते }\end{array}$ & $\begin{array}{l}\text { ते } \\
\text { ते }\end{array}$ & $\begin{array}{l}\text { Iิ } \\
\text { I }\end{array}$ & \begin{tabular}{l}
$\stackrel{1}{I}$ \\
\multicolumn{2}{c}{}
\end{tabular} & $\begin{array}{l}\text { ते } \\
\text { ते }\end{array}$ & 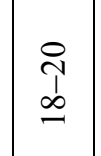 \\
\hline $\begin{array}{l}\overline{\bar{y}} \\
\overline{0}\end{array}$ & 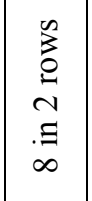 & 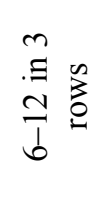 & 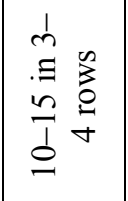 & $\begin{array}{l}n \\
\hat{0} \\
0 \\
0 \\
. \\
0\end{array}$ & $\begin{array}{l} \pm \\
\pm \\
\stackrel{\infty}{\Xi} \\
\stackrel{0}{0} \\
m\end{array}$ &  &  & $\begin{array}{l}\tilde{N} \\
\Xi \\
\hat{b} \\
b \\
b\end{array}$ & $\begin{array}{l}n \\
\vdots \\
0 \\
0 \\
0 \\
\infty \\
0 \\
0\end{array}$ & 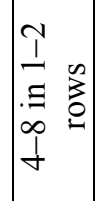 \\
\hline  & 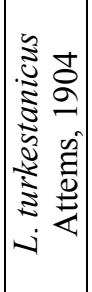 & 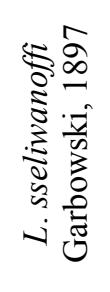 & 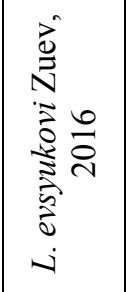 &  & 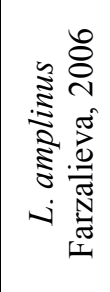 & 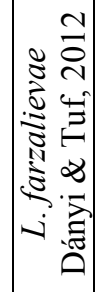 &  & 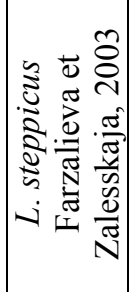 & 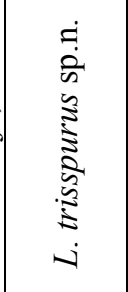 &  \\
\hline
\end{tabular}


Table 2. L. trisspurus sp.n. (holotype): plectrotaxy; spines in brackets are asymmetric. Таблица 2. L. trisspurus sp.n. (голотип): распределение шипов; шипы в скобках асимметричны.

\begin{tabular}{|c|c|c|c|c|c|c|c|c|c|c|}
\hline \multirow{2}{*}{$\begin{array}{c}\text { Leg } \\
\text { pairs }\end{array}$} & C & Tr & P & F & Ti & C & Tr & P & F & Ti \\
\cline { 2 - 11 } & & & & & & & & & \\
\hline 1 & - & - & $\mathrm{m}$ & $\mathrm{am}$ & $\mathrm{m}$ & - & - & $\mathrm{p}$ & $\mathrm{ap}$ & $\mathrm{a}(\mathrm{p})$ \\
\hline 2 & - & - & $\mathrm{m}$ & $\mathrm{am}$ & $\mathrm{m}$ & - & - & $\mathrm{p}$ & $\mathrm{ap}$ & $\mathrm{ap}$ \\
\hline $3-5$ & - & - & $\mathrm{p}$ & $\mathrm{am}$ & $\mathrm{am}$ & - & - & $\mathrm{p}$ & $\mathrm{ap}$ & $\mathrm{ap}$ \\
\hline $6-10$ & - & - & $\mathrm{p}$ & $\mathrm{am}$ & $\mathrm{am}$ & - & - & - & $\mathrm{ap}$ & $\mathrm{ap}$ \\
\hline 11 & - & - & $\mathrm{p}$ & $\mathrm{am}(\mathrm{p})$ & $\mathrm{am}$ & - & - & - & $\mathrm{p}$ & $\mathrm{ap}$ \\
\hline 12 & - & - & $\mathrm{p}$ & $\mathrm{am}$ & $\mathrm{am}$ & $\mathrm{a}$ & - & $\mathrm{mp}$ & $\mathrm{p}$ & $\mathrm{p}$ \\
\hline 13 & - & - & $\mathrm{p}$ & $\mathrm{amp}$ & $\mathrm{am}$ & $\mathrm{a}$ & - & $\mathrm{mp}$ & $\mathrm{p}$ & $\mathrm{p}$ \\
\hline 14 & - & $\mathrm{m}$ & $\mathrm{mp}$ & $\mathrm{am}$ & $\mathrm{m}$ & $\mathrm{a}$ & - & $\mathrm{mp}$ & $\mathrm{p}$ & $\mathrm{p}$ \\
\hline 15 & - & $\mathrm{m}$ & $\mathrm{mp}$ & $\mathrm{m}$ & - & $\mathrm{a}$ & - & $\mathrm{mp}$ & - & - \\
\hline
\end{tabular}

Table 3. L. trisspurus sp.n. (paratypes): plectrotaxy; spines in brackets are variable. Таблица 3. L. trisspurus sp.n. (паратипы): распределение шипов; вариабельные шипы в скобках.

\begin{tabular}{|c|c|c|c|c|c|c|c|c|c|c|}
\hline \multirow[b]{2}{*}{ Leg pairs } & \multicolumn{5}{|c|}{$\mathrm{V}$} & \multicolumn{5}{|c|}{$\mathrm{D}$} \\
\hline & $\mathrm{C}$ & $\operatorname{Tr}$ & $\mathrm{P}$ & $\mathrm{F}$ & $\mathrm{Ti}$ & $\mathrm{C}$ & $\operatorname{Tr}$ & $\mathrm{P}$ & $\mathrm{F}$ & $\mathrm{Ti}$ \\
\hline 1 & - & - & $\mathrm{m}$ & $\mathrm{am}$ & $\mathrm{m}$ & - & - & $\mathrm{p}$ & ap & $\mathrm{p}$ \\
\hline 2 & - & - & $\mathrm{m}$ & $\mathrm{am}$ & $\mathrm{m}$ & - & - & $p$ & ap & ap \\
\hline $3-5$ & - & - & $\mathrm{p}$ & am & $\mathrm{am}$ & - & - & $\mathrm{p}$ & ap & ap \\
\hline $6-10$ & - & - & $\mathrm{p}$ & $\mathrm{am}$ & $\mathrm{am}$ & - & - & - & ap & ap \\
\hline 11 & - & - & $\mathrm{p}$ & $\mathrm{am}$ & $\mathrm{am}$ & - & - & - & $\mathrm{p}$ & ap \\
\hline 12 & - & - & $\mathrm{p}$ & $\mathrm{am}$ & $\mathrm{am}$ & (a) & - & $\mathrm{mp}$ & $\mathrm{p}$ & $\mathrm{p}$ \\
\hline 13 & - & - & $\mathrm{p}$ & amp & $\mathrm{am}$ & $\mathrm{a}$ & - & $\mathrm{mp}$ & $\mathrm{p}$ & $\mathrm{p}$ \\
\hline 14 & - & $\mathrm{m}$ & $\mathrm{mp}$ & $\mathrm{am}$ & $\mathrm{m}$ & $\mathrm{a}$ & - & $\mathrm{mp}$ & $\mathrm{p}$ & $\mathrm{p}$ \\
\hline 15 & - & $\mathrm{m}$ & $\mathrm{mp}$ & $\mathrm{m}$ & - & $\mathrm{a}$ & - & $\mathrm{mp}$ & - & - \\
\hline
\end{tabular}

Table 4. L. monocoxaporus sp.n. (holotype): plectrotaxy. Таблица 4. L. monocoxaporus sp.n. (голотип): распределение шипов.

\begin{tabular}{|c|c|c|c|c|c|c|c|c|c|c|}
\hline \multirow{2}{*}{$\begin{array}{c}\text { Leg } \\
\text { pairs }\end{array}$} & \multicolumn{5}{|c|}{ V } & \multicolumn{5}{|c|}{ D } \\
\cline { 2 - 11 } & $\mathrm{C}$ & $\mathrm{Tr}$ & $\mathrm{P}$ & $\mathrm{F}$ & $\mathrm{Ti}$ & $\mathrm{C}$ & $\mathrm{Tr}$ & $\mathrm{P}$ & $\mathrm{F}$ & $\mathrm{Ti}$ \\
\hline 1 & - & - & $\mathrm{p}$ & $\mathrm{am}$ & $\mathrm{m}$ & - & - & $\mathrm{p}$ & $\mathrm{ap}$ & $\mathrm{ap}$ \\
\hline $2-4$ & - & - & - & $\mathrm{am}$ & $\mathrm{m}$ & - & - & $\mathrm{p}$ & $\mathrm{ap}$ & $\mathrm{ap}$ \\
\hline 5 & - & - & - & $\mathrm{am}$ & $\mathrm{m}$ & - & - & - & $\mathrm{ap}$ & $\mathrm{ap}$ \\
\hline $6-11$ & - & - & - & $\mathrm{am}$ & $\mathrm{am}$ & - & - & - & $\mathrm{ap}$ & $\mathrm{ap}$ \\
\hline 12 & - & - & $\mathrm{mp}$ & $\mathrm{amp}$ & $\mathrm{am}$ & $\mathrm{a}$ & - & $\mathrm{p}$ & $\mathrm{p}$ & $\mathrm{p}$ \\
\hline 13 & - & - & $\mathrm{mp}$ & $\mathrm{amp}$ & $\mathrm{am}$ & $\mathrm{a}$ & - & $\mathrm{mp}$ & $\mathrm{p}$ & $\mathrm{p}$ \\
\hline 14 & - & $\mathrm{m}$ & $\mathrm{amp}$ & $\mathrm{am}$ & $\mathrm{m}$ & $\mathrm{a}$ & - & $\mathrm{mp}$ & $\mathrm{p}$ & - \\
\hline 15 & - & $\mathrm{m}$ & $\mathrm{amp}$ & $\mathrm{m}$ & - & $\mathrm{a}$ & - & $\mathrm{mp}$ & - & - \\
\hline
\end{tabular}


Table 5. L. monocoxaporus sp.n. (paratypes): plectrotaxy; spines in brackets are variable. Таблица 5. L. monocoxaporus sp.n. (паратипы): распределение шипов; вариабельные шипы в скобках.

\begin{tabular}{|c|c|c|c|c|c|c|c|c|c|c|}
\hline \multirow{2}{*}{$\begin{array}{l}\text { Leg } \\
\text { pairs }\end{array}$} & \multicolumn{5}{|c|}{$\mathrm{V}$} & \multicolumn{5}{|c|}{$\mathrm{D}$} \\
\hline & $\mathrm{C}$ & $\mathrm{Tr}$ & $\mathrm{P}$ & $\mathrm{F}$ & $\mathrm{Ti}$ & $\mathrm{C}$ & $\operatorname{Tr}$ & $\mathrm{P}$ & $\mathrm{F}$ & $\mathrm{Ti}$ \\
\hline 1 & - & - & - & ap & $\mathrm{m}$ & - & - & $\mathrm{p}$ & ap & ap \\
\hline $2-3$ & - & - & - & am & $\mathrm{m}$ & - & - & $\mathrm{p}$ & ap & ap \\
\hline $4-8$ & - & - & - & am & $\mathrm{m}$ & - & - & - & ap & ap \\
\hline 9 & - & - & - & $\mathrm{am}$ & $\mathrm{m}$ & - & - & - & ap & ap \\
\hline 10 & - & - & - & am & am & - & - & - & ap & ap \\
\hline 11 & - & - & $\mathrm{p}$ & $\mathrm{am}$ & $\mathrm{am}$ & - & - & - & $\mathrm{p}$ & ap \\
\hline 12 & - & - & $\mathrm{p}$ & amp & $\mathrm{am}$ & (a) & - & $\mathrm{mp}$ & $\mathrm{p}$ & $\mathrm{p}$ \\
\hline 13 & - & - & $\mathrm{p}$ & (a)mp & $\mathrm{am}$ & $a$ & - & $\mathrm{mp}$ & $\mathrm{p}$ & $\mathrm{p}$ \\
\hline 14 & - & $\mathrm{m}$ & $\mathrm{mp}$ & ap & - & $\mathrm{a}$ & - & $\mathrm{mp}$ & $\mathrm{p}$ & (p) \\
\hline 15 & - & $\mathrm{m}$ & amp & (m) & - & $\mathrm{a}$ & - & $\mathrm{mp}$ & - & - \\
\hline
\end{tabular}

